\title{
DOI: https://doi.org/10.15407/pmach2021.02.059
}

UDC 519.853. 3

\section{AN ADAPTIVE METHOD FOR NUMERICAL DIFFERENTIATION OF DIFFICULT-TO- COMPUTE FUNCTIONS}

\section{Helii A. Sheludko}

ORCID: 0000-0003-4171-9591

\section{Serhii V. Ugrimov}

sugrimov@ipmach.kharkov.ua ORCID: 0000-0002-0846-4067

A. Pidhornyi Institute of Mechanical Engineering Problems of NASU 2/10, Pozharskyi St., Kharkiv, 61046, Ukraine
An adaptive approach to the numerical differentiation of difficult-to-compute functions is considered. Complex dependencies, which are the result of multiple superpositions of functions or the product of various algorithmic processes, are knowingly difficult to study directly. To establish the nature of the behavior of such dependencies, one has to resort to numerical analysis. One of the important characteristics of functions is a derivative, which indicates the direction and rate of change of a dependence. However, with difficult-to-compute functions, the available a priori information is not always sufficient to achieve the appropriate accuracy of the solution by known means. The loss of accuracy occurs due to the accumulation of round-off errors that grow in proportion to the number of calculated values of a function. In this case, it is necessary to pass on to the posterior approach in order to determine the behavior of the function and move away from the scheme of equidistant nodes, relying on an adaptive way of studying the local situation in the domain of the function. This paper implements an adaptive method for finding derivatives of a function with a minimum of restrictive requirements for the class of functions and the form of their assignment. Due to this, the costs of calculating the function have been significantly reduced with the result that their number has been brought to almost the optimal level. At the same time, the amount of RAM used has sharply decreased. There is no need for a preliminary analysis of the problem of establishing the class of the function under study, in the involvement of special functions or transformation of initial conditions for using standard tables of weight coefficients, etc. For research, it is enough to assign a continuous and bounded function on a fixed segment and a minimum step, which is indirectly responsible for ensuring the required accuracy of differentiation. The effectiveness of the proposed method is demonstrated on a number of test examples. The developed method can be used in more complex problems, for example, in solving some types of differential and integral equations, as well as for a wide range of optimization problems in a wide variety of areas of applied analysis and synthesis.

Keywords: non-differentiable function, piecewise linear approximation, adaptive step-by-step selection of nodes.

\section{Introduction}

The list of problems leading to the necessity of calculating the derivative of a function is extremely diverse and numerous [1-4]. In fact, in order to analyze the characteristics of processes, as well as estimations associated with the accuracy of the solutions obtained, they resort to the use of derivatives that establish the rate of change of a particular feature, its extreme properties, etc.

The class of functions offered by practice is very wide, and the functions themselves are often difficult to compute [5-7]. Sometimes they are represented by complex analytical structures (for example, multiple superpositions of functions, experimental results), or are defined algorithmically. Therefore, one has to focus on the numerical methods that do not impose strict requirements on the function $f(x)$, except that they require its continuity with a finite number of singularities in the segment $[A, B]$.

Differentiation of elementary functions is a fairly simple operation. In the general case, the error in the approximate derivation of the derivative $m$ of order $f^{(m)}\left(x^{*}\right)$ at the point $x^{*} \in[A, B]$ from the given table function $y=f(x)$ (at the nodes $A \leq x_{0}<x_{1}<\ldots<x_{n} \leq B$ the function values $y_{0}, y_{1}, \ldots, y_{n}$ are known) can be represented in the form $[8,9]$

$$
R_{n}^{(m)}\left(x^{*}\right)=f^{(m)}\left(x^{*}\right)-P_{n}^{(m)}\left(x^{*}\right)=\frac{\omega^{(m)}\left(x^{*}\right)}{(n+1) !} f^{(n)}(\xi)
$$

provided that the function is $n+1$ times continuously differentiable on the segment $[A, B]$. Here, $P_{n}(x)$ is an interpolation polynomial satisfying the conditions

This work is licensed under a Creative Commons Attribution 4.0 International License.

(C) Helii A. Sheludko, Serhii V. Ugrimov, 2021 


$$
P_{n}\left(x_{i}\right)=f\left(x_{i}\right), \quad\left\{x_{i}\right\} \in[A, B], \quad \omega(x)=\prod_{i=0}^{n}\left(x-x_{i}\right) \quad \xi \in[A, B] .
$$

Such a scheme, based on the Lagrange interpolation formula $[8,9]$, most often provides for equally spaced nodes $x_{i} \in[A, B]$. As a result, the function is assumed to behave similarly in certain sub-segments of the segment $[A, B]$, which may entail a loss of the required accuracy of calculating the derivative $f^{(m)}\left(x^{*}\right)$. A simple increase in the number $n$ of the nodes $x_{i}$ does not always solve this problem, since the closeness of the functions $f\left(x_{i}\right)$ and $P_{n}\left(x_{i}\right)$ still does not guarantee the closeness of their derivatives at other points, especially since the error increases due to the accumulation of round-off errors. With large $n$, small errors in the values of $f_{i}$ can result in large errors [9-11].

For approximate differentiation, formulas based on the Gregory-Newton and Newton-Stirling interpolants are widely used [10]. However, in the first case, one often has to deal with relatively large coefficients with divided differences, which entails a loss of accuracy, and in the second one, an error occurs due to the use of a smaller number of significant digits in the finite differences, and therefore in the calculated values of derivatives.

Applying any formula of approximate differentiation, one always introduces a number of assumptions and restrictions regarding the properties of the function, for example, the absence of rapidly oscillating components, the period of which does not exceed the step size. The use of usual differentiation formulas (Newton, Stirling, etc.) presupposes a certain "correctness" in the behavior of finite differences for given equally-spaced grid nodes. If such correctness is violated, then every time it is necessary to conduct a special study of the nature of the function.

An attempt to select an optimal differentiation step, posed as the problem of minimizing the sum of truncation and round-off errors, solves the question, but only for a specific function [11, 12].

Since with the nonlinear transcendental functions $f(x)$ the use of divided differences for approximation is problematic, then one tries to compensate for the lack of information about the nature of the function by simply increasing the number of nodes, which is not always justified. This is especially noticeable in the case of difficult-to-compute functions [13].

It would seem that it could be more convenient here to approximate the functions $f(x)$ by splines [12]. They have greater local flexibility. Even with a small degree $n$ of the polynomial (three, five), splines show good results in the selected sub-segment of the segment $[A, B]$. But again, the question of using the nodes $x_{i}$ to preliminary divide the segment $[A, B]$ into sub-segments remains open. Therefore, for difficult-tocompute functions, one can expect to obtain a derivative of only a limited level of accuracy. The reduction of the derivative calculation error when dividing the segment $[A, B]$ into an increasing number of sub-segments ( $n>5$ splines) is rather slow. At the same time, the complexity of calculations increases significantly due to the appearance of a large number of coefficients in the formulae used.

The aim of the proposed work is to increase the efficiency of approximate differentiation in conditions of poor awareness of the nature of the behavior of an undoubtedly difficult-to-compute function.

\section{Problem Formulation}

The main source of error in calculating derivatives (especially for difficult-to-compute functions) is, on the one hand, the number $n$ of its calculations, and, on the other hand, the uncertainty of the method of dividing the segment $[A, B]$ into small sub-segments, with a previously unknown character of behavior of the function $y=f(x)$. This circumstance forces us to abandon the a priori assignment of the number of nodes $n$ and turn to their a posteriori selection based on the analysis of the emerging search situation. Such a choice of points for a function given over an interval of great length puts forward stringent requirements for the construction of the computational process. It should provide qualitative tracking of changes in the behavior of the function over the entire interval under study.

Striving for the most economical and simple way of approximating the original function $f(x)$, given by a discrete

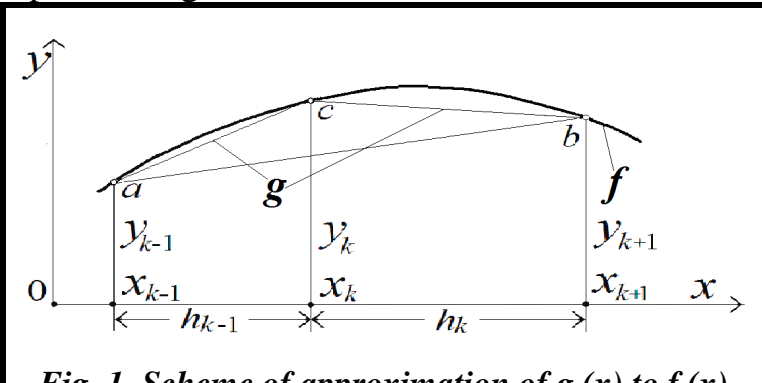

Fig. 1. Scheme of approximation of $g(x)$ to $f(x)$ 
set of its values, leads to the use of first-order splines, i.e. to a piecewise linear approximation $g(x)$ (Fig. 1). This gives rise to unwanted breaks in the function $g(x)$. However, the derivative at point $c$ (see Fig. 1) can be approximately represented by its piecewise-difference analogue, using, for example, the weighted-slope method [14]. The accuracy of the approximation of the derivative $f^{\prime}(x)$ at point $c$ with left-hand $\Delta_{c a}$, and right-hand $\Delta_{b c}\left(\Delta_{u v}=(f(u)-f(v)) /(u-v)\right)$ differences is proportional to the distance of points $a$ and $b$ from $c$. Therefore, putting

we come to the weighted-slope method

$$
\Delta_{c}=\left[(b-c) \Delta_{c a}+(c-a) \Delta_{b c}\right] /(b-a),
$$

$$
\Delta_{c}=\Delta_{c a}+\Delta_{b c}-\Delta_{b a}
$$

In this case, the derivative at point $c$ of the function $f(\mathrm{x})$ is replaced by weighted average approximation, when the role of weights is played by corresponding ratios of the lengths of the arcs $\hat{c a} / \hat{b a}$ and $\hat{b c} / \hat{b a}$. Coarsening the derivative approximation, one can replace the lengths of the arcs $\hat{b c}$ and $\hat{c a}$ with the lengths of the chords $\overline{b c}$ and $\overline{c a}$ that contract them, i.e. put

$$
\Delta_{c} \approx \frac{\overline{b c}}{\overline{b c}+\overline{c a}} \Delta_{c a}+\frac{\overline{c a}}{\overline{b c}+\overline{c a}} \Delta_{b c} .
$$

The smaller the neighborhood of point $c$, the closer $\Delta_{c}$ to $f^{\prime}(c)$.

The error in the approximation of the derivative of the given function $f(x)$ at point $c$ can be represented by the value

$$
\delta=\left|\Delta_{c}-f^{\prime}(c)\right|=\frac{(c-a)(c-b)(c-d)}{3 !} \max _{x \in I}\left|f^{(3)}(x)\right|, \quad I=[a, b, c, d],
$$

assuming that $\max _{x \in I}\left|f^{(3)}(x)\right| \approx f^{(3)}((c+b) / 2)$ and counting approximately

$$
f^{(3)}(x) \approx 3\left(\Delta_{b}^{\prime \prime}-\Delta_{c}^{\prime \prime}\right) /(d-a),
$$

where $\Delta_{b}^{\prime \prime} \approx 2\left(\Delta_{d b}-\Delta_{b c}\right) /(d-c), \Delta_{c}^{\prime \prime} \approx 2\left(\Delta_{b c}-\Delta_{c a}\right) /(b-a)$.

The division of the segment $[A, B]$ into sub-segments with different behavior of the function $f(x)$ will be carried out according to the change in the value of the discriminant

$$
D=\varepsilon-\sigma_{k},
$$

where $\varepsilon$ is a given average level of accuracy for the entire region of differentiation of the function $f(x)$, and $\sigma_{k}$ is a criterion for a local situation $[15,16]$. Let us agree to determine $\sigma_{k}$ (see Fig. 2) as follows

$$
\begin{gathered}
\sigma_{k}=\left|y_{k}^{*}-g_{k}^{*}\right|, \\
y_{k}^{*}=0.25\left|\left(1+\lambda_{k}\right) y_{k+1}+3 y_{k}-\lambda_{k} y_{k-1}\right|, \quad \lambda_{k}=h_{k} /\left(h_{k}+h_{k-1}\right), \\
g_{k}^{*}=0.5\left(y_{k}+y_{k+1}\right), \quad x_{k}^{*}=0.5\left(x_{k}+x_{k+1}\right) .
\end{gathered}
$$

The situation $\sigma_{k}$ models the proximity of the function $f(x)$ to the broken line $\mathrm{g}(x)$ approximating it at the place of the probable largest deviation of the function $f(x)$ from $g(x)$, i.e. in the vicinity of the point $x_{k}^{*}$. For this, the direction of the derivative $\overline{a e} \| \overline{l b}$ at point $a$ is used, and not the direction of the previous chord $\overline{l a}$. Thus, if the method of approximate differentiation, even at the most unfavorable points of the form $x_{k}^{*}$, provides the given accuracy, then in all other cases an acceptable result is guaranteed. The choice of the point $c=(e+d) / 2$ accepted here (see Fig. 2) pursues the only objective - to simplify the approximation algorithm as much as possible.

To obtain the new points $x_{k+1}=x_{k}+h_{k}$, the adaptive choice of which is determined by the situation $\sigma_{k}$, which describes the behavior of the function $f(x)$ in the segment $[A, B]$ in the vicinity of the point $x_{k}^{*}$, we use the controlled process [14-16] 


$$
h_{k+1}=h_{k} \exp (\alpha D), \quad \alpha>0 .
$$

Here, the coefficient $\alpha$ is responsible for the degree of influence of the evolving situation on the rate of change of steps in (5).

Changing $D$ in (5) increases (or decreases) the step size $h_{k+1}$. Thus, this indirectly affects the accuracy of calculating the derivative through the accuracy of the approximation of the function $f(x)$.

As it is shown in figure 2, monitoring the local situation $\sigma_{k}(4)$ together with the level of accuracy $\varepsilon$ and with account of (3) can serve as a control action in the step process (5), i.e.

$$
h_{k+1}=h_{k} \exp \left[\alpha\left(\varepsilon-\sigma_{k}\right)\right] .
$$

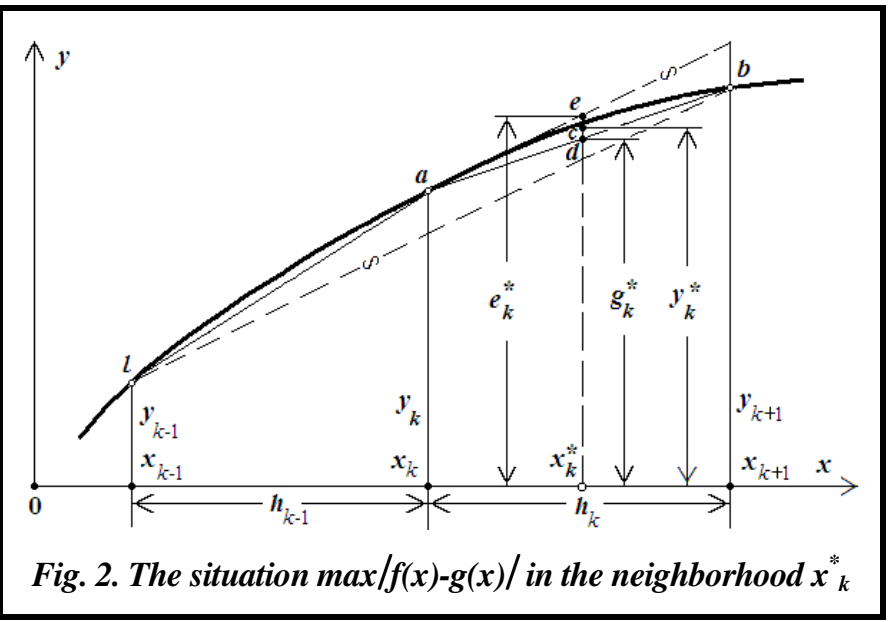

To accelerate the advance along the segment $[A, B]$, we take some $\varepsilon>\sigma_{0}$, which can remain constant or be rearranged in the course of process (6) in accordance with the degree of change in the situation $\sigma_{k}$.

The value of the initial step $h_{0}$ of process (6) is determined from the condition of the positiveness of the discriminant $D$, i.e. choosing $\varepsilon>\sigma_{k}$, for example, $\varepsilon=(1.01 \div 1.1) \sigma_{0}$, since there is not enough information about the function $f(x)$ and the distribution of its characteristic points of different nature (extreme points, kinks, etc.) in the given segment $[A, B]$.

When approaching neighborhoods with kinks or extreme points, the angle between the directions of derivatives at the neighboring points $x_{k-1}, x_{k}$ noticeably increases, which accordingly entails a sharp decrease in the step, down to values close to $h_{\min }$, below which it is no longer advisable to distinguish the change of the function $f(x)$ for its approximation. But if the indicated neighborhood has already been passed and $D>0$, then to accelerate process (6), we can return to the initial step, for example, $h_{0}=(1.1 \div 1.2) h_{\min }$.

Passing the segment [A, B] by the adaptive method (6) in $N$ calculations of the function $f(x)$ makes it possible to obtain the same number of values of the approximate derivative $\Delta_{c}(2)$.

Using the example of the simple function $f(x)=\sqrt{x}[0.01 ; 1.01]$, we will start and exit the program when the adaptive differentiation method is applied. Fig. 3 shows the exact behavior of the derivative $f^{\prime}(x)$ on the segment $[A, B]$, as well as the points of its approximate value $\Delta(2)$.

After two equal initial steps $h_{0}=h_{1}=0.01$, determined by the accepted value $h_{\min }=0.005$, have been taken, it becomes possible to calculate the criterion of the local situation (4) $\sigma_{k}=0.009637592$ and assign the value $\varepsilon=0.01>\sigma_{k}$ with account of $\sigma_{k}$ for the main mechanism (6) of the variable step to be included in the process.

Since the last step $h_{33}=0.01703624$ of process (6) places the last point $x_{33}=1.041639436$ outside the point $B=1.01$ of the segment $[A, B]$, the algorithm replaces the value of $x_{33}$ with the value $B=1.01$. The result was obtained at an intensity equal to $\alpha=10$.

If the derivative approximation process were carried out with the same but constant step $h=h_{0}$, which ensures the obtained average accuracy, then on a given interval it would be necessary to compute the function 100 times instead of 33 .

As we can see, the adaptive action of formula (6) is aimed not only at choosing the appropriate steps in order to reduce computational costs, but also at creating favorable conditions for a better approximation of the derivatives (2). At the same time,



Fig. 3. Derivative $f^{\prime}(x)$ and its approximation $\Delta$ 
when process (6) falls into the neighborhood of a sharp change in the behavior of the function $f(x)$, characterized by criterion (4), the use of the weighted slope method (2) may be insufficient to ensure the proper level of accuracy of the derivative. In this case, in the sub-segments with a sharp change in the behavior of the function, it is necessary to switch to a simple sub-segment scanning with a deliberately reduced step, close to $h_{\min }$. This partly contributes to the non-omission of singularities of the function $f(x)$.

\section{Numerical Experiment}

The accepted method of numerical differentiation (2)-(6) was tested on the many examples of functions of different complexity. Some of the test functions that have sharp local changes in behavior including "kinks" are presented below [8, 10-12, 17-24]

$$
\begin{gathered}
f_{\mathrm{I}}=x \sin (1 / x) ; \quad f_{\mathrm{II}}=\left|(|x|-1)^{3}\right| ; \quad f_{\mathrm{III}}=|\sin x+\sin 2 x| ; \quad f_{\mathrm{IV}}=|x-e| /\left(4+x^{2}\right)^{0.5} ; \\
f_{\mathrm{V}}=\left|\sin \left(x^{3} / 20\right)\right| ; \quad f_{\mathrm{VI}}=\left|\left(2 \pi x^{2}-x^{3}\right)^{1 / 3}\right| ; \quad f_{\mathrm{VII}}=(\operatorname{tg} 3 x)^{1 / 3} ; \quad f_{\mathrm{VIII}}=\left(3 x^{5}-25 x^{3}+60 x+16\right) / 15 ; \\
f_{\mathrm{IX}}=|\operatorname{arctg}[(x-3) /(x+4)]| ; \quad f_{\mathrm{X}}=|\sin (\ln x)| ; \quad f_{\mathrm{XI}}=\left(e^{x}-1\right)^{2}+\left[\left(1+x^{2}\right)^{-0.5}-1\right]^{2} ; \quad f_{\mathrm{XII}}=|\ln (\operatorname{arctg} x)| ; \\
f_{\mathrm{XIII}}=\sin \left(2^{\left[\lg _{7}(1+\operatorname{tg}(x+1))\right]^{0.2}}\right) ; \quad f_{\mathrm{XIV}}=\sqrt[3]{x}-\sqrt[3]{x+1} ; \quad f_{\mathrm{XV}}=(2-\cos x-\cos 2 x)^{0.5} ; \quad f_{\mathrm{XVI}}=\exp \left(3 x^{2}-x^{3}\right)^{1 / 3} ; \\
f_{\mathrm{XVII}}=\sin x+\sin (10 x / 3)+\ln x-0.84 x+3 ; \quad f_{\mathrm{XVIII}}=-\left\{\sin \left[\pi\left(1-x^{2}\right)^{0.5}\right]+x+\pi+1\right\} ; \\
f_{\mathrm{XIX}}=\operatorname{arctg}\left[(x-8) /\left(x^{2}+4\right)\right] ; \quad f_{\mathrm{XX}}=x /\left(1+x^{2} \sin ^{2} x\right) .
\end{gathered}
$$

Let us introduce a simple concept of the unit cost of obtaining the integral averaged error in calculating the derivatives in the segment $[A, B]$ in the form

$$
C=N \sum_{k=1}^{N}\left|f_{k}^{\prime}-\Delta_{k}^{*}\right| /(B-A),
$$

where $f_{k}^{\prime}$ is the "exact" value and $\Delta_{k}^{*}=\Delta\left(x_{k}^{*}\right)$ is the approximate value of the derivatives at the corresponding nodes $x_{k}^{*} ; N$ is the cost of achieving the desired result by this method, i.e. the number of evaluations of the functions $f(x)$ for this.

It is clear that the efficiency of the method, shown in solving a specific problem, is the greater the lower the cost $C$ (7), other things being equal.

We assume that scanning the same segment $[A, B]$ with the smallest possible step $h_{\min }$ provides a more accurate approximation of the derivatives. Then we arrive at the inequality

$$
\sum_{i=1}^{N^{\prime}}\left|f_{i}^{\prime}-\Delta_{i}^{*}\right| \leq \sum_{k=1}^{N}\left|f_{k}^{\prime}-\Delta_{k}^{*}\right|
$$

where $i \vee k$ are the numbers of the nodes of the corresponding grids, and $N$ is the integer part $\left[(B-A) / h_{\min }\right]$.

Based on (8), the effectiveness of method (2)-(6) will be conditionally estimated using the simplified quality criterion ("efficiency index" [25])

$$
E=\frac{C_{\text {scan }}}{C_{\text {adap }}}=\frac{N^{\prime} \sum_{i=1}^{N^{\prime}}\left|f_{i}^{\prime}-\Delta_{i}^{*}\right|}{N \sum_{k=1}^{N}\left|f_{k}^{\prime}-\Delta_{k}^{*}\right|}
$$

i.e., the ratio of the costs of achieving the corresponding mean-integral absolute errors on the same segment $[A, B]$, but on different $i \vee k$ grids.

Criterion (9) contains the well-known principle of equal influences, when it is assumed that the total absolute error on the entire segment $[A, B]$ does not exceed a given value. For convenience, the "exact" value $f_{k}^{\prime}$ of the derivative in all the above examples was calculated by the formula

where $\delta=10^{-10}$.

$$
\left(f\left(x_{k}^{*}+\delta\right)-f\left(x_{k}^{*}-\delta\right)\right) / 2 \delta
$$


These costs, of course, are not included in the number of $N$ and $N$.

The table shows the results of calculating the efficiency criterion $E$ (9) for functions I-XX in an adaptive way and the achieved cost of $C_{a d a p}$ in the segment $[A, B]$. Here, a specific case of using the constant, on the sub-segments $\left[x_{k}, x_{k+1}\right]$, precision value $\varepsilon=0.001, \alpha=10, h_{0}=h_{\min }=0.001$.

Efficiency of finding derivatives by the adaptive method for test functions specified in the segment [A, B]

\begin{tabular}{c|c|c|c|c}
\hline$f(x)$ & {$[A, B]$} & $C_{\text {adap }}$ & $N$ & $E$ \\
\hline I & {$[0.2 / \pi ; 5 / \pi]$} & 73.93731498 & 25 & 4.493741243 \\
\hline II & {$[-0.995 ; 2]$} & 38.67561466 & 190 & 4.388755049 \\
\hline III & {$[0 ; 2 \pi]$} & 200.8427336 & 625 & 1.006234064 \\
\hline IY & {$[-2.995 ; 4]$} & 10.13399088 & 693 & 1.011373266 \\
\hline Y & {$[0 ; 3 \pi / 2]$} & 135.9652785 & 307 & 1.773252544 \\
\hline YI & {$[-1 ; 3.5]$} & 242.4711093 & 390 & 1.175904877 \\
\hline YII & {$[0 ; 2 \pi]$} & 300.2439079 & 31 & 126.3714985 \\
\hline YIII & {$[0 ; 4.5]$} & 150.9098132 & 451 & 4.666437614 \\
\hline IX & {$[-\pi ; \pi]$} & 3.029803189 & 430 & 1.58827937 \\
\hline X & {$[0.01 ; 5]$} & 343.3627677 & 90 & 5.467829259 \\
\hline XI & {$[-2 ; 5]$} & 3365.971896 & 657 & 1.088513516 \\
\hline XII & {$[0.01 ; \pi]$} & 54.35070561 & 39 & 7.146833836 \\
\hline XIII & {$[-1.75 ; 0.56]$} & 909.3456208 & 125 & 1.885660155 \\
\hline XIY & {$[-1 ; 2]$} & 200.9964238 & 94 & 15.46132117 \\
\hline XY & {$[-\pi ; \pi]$} & 14.62555623 & 419 & 3.433101097 \\
\hline XYI & {$[-1 ; 1.6]$} & 57.04142104 & 156 & 3.918496306 \\
\hline XYII & {$[0.1 ; 3.5]$} & 5.518200797 & 142 & 1.213207504 \\
\hline XYIII & {$[-1 ; 1]$} & 269.4804473 & 27 & 10.13027855 \\
\hline XIX & {$[0 ; 1]$} & 126.9048103 & 25 & 4.817065532 \\
\hline XX & {$[-\pi / 4 ; 3 \pi]$} & 45719.13737 & 549 & 2.803608813 \\
\hline
\end{tabular}

It can be seen from the table that the proposed method of adaptive differentiation for the considered test functions, given on segments of different lengths and with different characteristic points, showed a fairly good process efficiency with a completely acceptable result error (despite the constant precision level $\varepsilon$ accepted for all test examples). Almost always, the adaptive method in the segment $[A, B]$ achieves a smaller average differentiation error than in the case of a simple scanning with the step $h_{\min }$, and therefore, for all examples, the value $E>1$. When approaching the neighborhood with a sharply changing situation $\sigma_{k}$, when the values of $\sigma_{k}$ and $\varepsilon$ turn out to be weakly correlated, it is necessary to reduce the step to a minimum, changing the derivative $\Delta_{c}$ (2) for $\Delta_{b c}$. The coincidence or proximity of the results of the costs to be compared (9) is possible only if, in methods like $S c a n$, any of the points $x_{k}$ turns out to be incidental to the center of a sharp symmetric break in the function $f(x)$ with its weakly curved, almost linear sides. Although, in general, this is unlikely.

\section{Conclusions}

The article implements an adaptive method for finding derivatives of a function with a minimum of restrictive requirements for the class of functions and the form of their assignment. For real problems, especially high accuracy of the result is not often required, however, large numerical costs are undesirable, which is why the main emphasis in the implementation of the method was aimed at the efficiency of the differentiation process. To implement the method, neither a preliminary research of the given function nor the use of its transformations is required. This is especially important in the case of noticeable nonlinearity, most often inherent in difficult-to-compute functions. In fact, the minimum information is used, which ensures the specified accuracy of differentiation, without resorting in advance to one or another special method of region discretization.

With the help of the created step-by-strep method for clarifying the situation and a simple technique for calculating the local derivative, it was possible to limit ourselves to piecewise linear approximation, when all the required conditions are easily satisfied without unnecessary numerical costs. The effectiveness of the proposed method is demonstrated on a variety of examples of differentiation of functions of different levels 
of complexity, some of which have sharp local changes in behavior, including "kinks". A numerical experiment showed a noticeable increase in efficiency when using the developed adaptive method in comparison with the known methods of approximate differentiation.

The proposed approach of approximate adaptive differentiation, which occurs in an automatic mode, may turn out to be convenient for solving some classes of differential and integral equations evolving in a variety of applied areas.

\section{References}

1. Mhaskar, H. N., Naumova, V., \& Pereverzyev, S. V. (2013). Filtered Legendre expansion method for numerical differentiation at the boundary point with application to blood glucose predictions. Applied Mathematics and Computation, vol. 224, pp. 835-847. https://doi.org/10.1016/j.amc.2013.09.015.

2. Sheludko, H. A., Shupikov, O. M., Smetankina, N. V., \& Ugrimov, S. V. (2001). Prykladnyy adaptyvnyy poshuk [Applied Adaptive Search]. Kharkiv: Vydavnytstvo "Oko", 191 p. (in Ukrainian).

3. Grakovski, A. \& Alexandrov A. (2005). Spectral method for numerical calculation of derivatives in digital processing of subsurface radar sounding signals. Mathematical Modelling and Analysis, vol. 10, no. 1, pp. 31-40. https://doi.org/10.1080/13926292.2005.9637268.

4. Zhao, Z. (2021). A Hermite extension method for numerical differentiation. Applied Numerical Mathematics, vol. 159, pp. 46-60. https://doi.org/10.1016/j.apnum.2020.08.016.

5. Il'in, V. P. \& Zadorin, A. I. (2019). Adaptive formulas of numerical differentiation of functions with large gradients. Journal of Physics: Conference Series, vol. 1260, iss. 4, pp.042003-1-042003-7. https://doi.org/10.1088/17426596/1260/4/042003.

6. Lu, S. \& Pereverzev, S. V. (2006) Numerical differentiation from a viewpoint of regularization theory. Mathematics of Computation, vol. 75, no. 256, pp. 1853-1870. https://doi.org/10.1090/S0025-5718-06-01857-6.

7. Zhao, Z. \& You, L. (2021). A numerical differentiation method based on Legendre expansion with super order Tikhonov regularization. Applied Mathematics and Computation, vol. 393. https://doi.org/10.1016/j.amc.2020.125811.

8. Krylov, A. N. (1954). Lektsii o priblizhennykh vychisleniyakh [Lectures on approximate calculations]. Moscow: Gostekhizdat, 98 p. (in Russian).

9. Goncharov, V. L. (1954). Teoriya interpolirovaniya i priblizheniya funktsiy [Theory of interpolation and approximation of functions]. Moscow: Gostekhizdat, 386 p. (in Russian).

10. Melentyev, P. V. (1966). Priblizhennyye vychisleniya [Approximate calculations]. Moscow: Fizmatgiz, 388 p. (in Russian).

11. Chebyshev, P. L. (1948). O funktsiyakh, malo uklonyayushchikhsya ot nulya pri nekotorykh velichinakh peremen$n y k h$ [On functions that deviate little from zero for some variables]. Complete works: In 5 vols. Vol. 3: Mathematical analysis. Moscow, Leningrad: Izd-vo AN SSSR, pp. 110-127 (in Russian).

12. Ahlberg, J. H., Nilson, E. N., \& Walsh, J. L (1967). The theory of splines and their applications. New York and London: Academic Press, $284 \mathrm{p}$.

13. Bellman, R. E., Dreyfus S. E. (2015). Applied Dynamic Programming. Princeton University Press, 390 p.

14. Sheludko, G. A., Strelnikova, Ye. A., \& Kantor, B. Ya. (2008). Gibridnyye metody v zadachakh optimalnogo proyektirovaniya. Poiskovyye metody [Hybrid methods in optimal design problems. Search methods]. Kharkov: Novoye slovo, 188 p. (in Russian).

15. Sheludko, H. A. \& Ugrimov, S. V. (2011). Adaptivnaya gibridizatsiya [Adaptive hybridisation]. Kharkov: Miskdruk, 308 p. (in Russian).

16. Sheludko, G. A. \& Ugrimov, S. V. (2018). Modernization adaptive piecewise linear approximation of difficultto-compute functions. Journal of Mechanical Engineering, vol. 21, no. 2, pp.60-67. https://doi.org/10.15407/pmach2018.02.060.

17. Bakhvalov, N. S. (1975). Chislennyye metody [Numerical methods]. Moscow: Nauka, 632 p. (in Russian).

18. Ramm, A. G. (1968). O chislennom differentsirovanii [On numerical differentiation]. Izvestiya vuzov. MatematikaNews of Universities. Mathematics, no. 11, pp. 131-134 (in Russian).

19. Gill, P. E., Murray, W., \& Wright, M. H. (1981). Practical Optimization. London: Academic Press, 401 p.

20. Tikhomirov, V. M. (1986). Rasskazy o maksimumakh i minimumakh [Narratives about maximums and minimums]. Moscow: Nauka, 192 p. (in Russian).

21. Forsythe, G. E., Malcolm, M. A., \& Moler, C. B. (1977). Computer methods for mathematical computations. Englewood Cliffs, New Jersey: Prentice-Hall, 259 p.

22. Gander, W. \& Gautschi, W. (2000). Adaptive quadrature - revisited. BIT Numerical Mathematics, vol. 40, iss. 1, pp. 84-101. https://doi.org/10.1023/A:1022318402393.

23. Mathews, J. \& Fink, K. (2004). Numerical methods using Matlab. New Jersey: Prentice-Hall, 696 p. 
24. Dolgopolova, T. F. \& Ivanov, V. K. (1966). O chislennom differentsirovanii [About numerical differentiation]. Zhurnal vychislitelnoy matematiki i matematicheskoy fiziki - Journal of Computational Mathematics and Mathematical Physics, vol. 6, no. 3, pp. 57-71 (in Russian). https://doi.org/10.1016/0041-5553(66)90145-5.

25. Ostrovskiy, A. M. (1966). Solutions of equations and systems of equations. New York: Academic Press, 338 p.

Received 29 March 2021

\title{
Адаптивний метод чисельного диференціювання важкообчислювальних функцій
}

\section{Г. А. Шелудько, С. В. Угрімов}

\author{
Інститут проблем машинобудування ім. А. М. Підгорного НАН України,
} 61046, Україна, м. Харків, вул. Пожарського, 2/10

Розглянуто адаптивний підхід до чисельного диферениіювання важкообчислювальних функиій. Складні залежності, які є результатом багаторазових суперпозицій функцій або різних алгоритмічних процесів, складні для безпосереднього дослідження. Для встановлення характеру поведінки таких залежностей доводиться вдаватися до чисельного аналізу. Однією з важливих характеристик функиій є похідна, яка вказує напрям $i$ швидкість зміни залежності. Однак при складнообчислювальних функціях наявної апріорно інформації не завжди достатньо, щоб відомими засобами можна було б досягти належної точності розв'язку. Втрата точності відбувається внаслідок накопичення помилок округлення, які зростають пропориійно кількості задіяних значень функиіі. У изьому випадку доводиться переходити до апостеріорного підходу для того, щзоб визначити поведінку функиії та відійти від схеми рівновіддалених вузлів, спираючись на адаптивний спосіб вивчення локальної обстановки в області визначення функиіі. У статті реалізовано адаптивний метод пошуку похідних функиї при мінімумі обмежувальних вимог до класу функцій і форми їх задання. Завдяки цььому значно зменшилися витрати на обчислення функиії, в результаті чого кількість обчислень було доведено майже до оптимального рівня. При иьому різко знизився обсяг використовуваної оперативної пам'яті. Немає потреби в проведенні попереднього аналізу зі встановлення класу досліджуваної функиії, в залученні спецфункиій або перетворенні початкових умов для використання стандартних таблиць вагових коефіиієнтів i т.n. Для дослідження достатньо задати неперервну і обмежену функиію на фіксованому сегменті і мінімальний крок, якій побічно відповідає за забезпечення необхідної точності диференціювання. Ефективність запропонованого методу демонструється на ряді тестових прикладів. Розроблений метод може бути використано у більш складних задачах, наприклад, при розв'язанні деяких типів диференціальних і інтегральних рівнянь, а також для широкого ряду задач оптимізаиії в найрізноманітніших областях прикладного аналізу та синтезу.

Ключові слова: недиференційована функиія, кусково-лінійне наближення, адаптивний покроковий вибір вузлів.

\section{Література}

1. Mhaskar H. N., Naumova V., Pereverzyev S. V. Filtered Legendre expansion method for numerical differentiation at the boundary point with application to blood glucose predictions. Appl. Mathematics and Computation. 2013. Vol. 224. P. 835-847, https://doi.org/10.1016/j.amc.2013.09.015.

2. Шелудько Г. А., Шупіков О. М., Сметанкіна Н. В, Угрімов С. В. Прикладний адаптивний пошук. Х.: Око, $2001.188 \mathrm{c}$.

3. Grakovski A., Alexandrov A. Spectral method for numerical calculation of derivatives in digital processing of subsurface radar sounding signals. Math. Modellingand Analysis. 2005. Vol. 10. No.1. P. 31-40. https://doi.org/10.1080/13926292.2005.9637268.

4. Zhao Z. A Hermite extension method for numerical differentiation. Appl. Numerical Mathematics. 2021. Vol. 159. P. 46-60. https://doi.org/10.1016/j.apnum.2020.08.016.

5. Il'in V. P., Zadorin A. I. Adaptive formulas of numerical differentiation of functions with large gradients. J.: Conf. Series. 2019. Vol. 1260. Iss. 4. P. 042003-1-042003-7. https://doi.org/10.1088/1742-6596/1260/4/042003.

6. Lu S., Pereverzev S. V. Numerical differentiation from a viewpoint of regularization theory. Mathematics Computation. 2006. Vol. 75. No. 256. P. 1853-1870. https://doi.org/10.1090/S0025-5718-06-01857-6.

7. Zhao Z., You L. A numerical differentiation method based on legendre expansion with super order Tikhonov regularization. Appl. Mathematics and Computation. 2021. Vol. 393. https://doi.org/10.1016/j.amc.2020.125811.

8. Крылов А. Н. Лекции о приближенных вычислениях. М.: Гостехиздат, 1954. 98 с.

9. Гончаров В. Л.. Теория интерполирования и приближения функций. Изд. 2. М: Гостехиздат, 1954. 386 с. 
10. Мелентьев П. В.. Приближенные вычисления. М.: Физматгиз, 1966. 388 р.

11. Чебышев П. Л. О функциях, мало удаляющихся от нуля при некоторых величинах переменных. Полн. собр. соч. в 5 т. Т. 3: Математический анализ. М.; Л.: Изд-во АН СССР, 1948. С. 108-127.

12. Алберг Дж., Нильсон Э., Уолш Дж. Теория сплайнов и её приложения. М.: Мир, 1977. 349 с.

13. Беллман Р., Дрейфус С. Прикладные задачи динамического программирования. М.: Наука, 1964. 385 с.

14. Шелудько Г. А., Стрельникова Е. А., Кантор Б. Я. Гибридные методы в задачах оптимального проектирования. Поисковые методы. Харьков: Новое слово, 2008. 188 с.

15. Шелудько Г. А., Угримов С. В. Адаптивная гибридизация. Х.: Міськдрук, 2011. 308 с.

16. Sheludko G. A., Ugrimov S. V. Modernization adaptive piecewise linear approximation of difficult-to-compute functions. J. Mech Eng. 2018. Vol. 21. No. 2. P. 60-67. https://doi.org/10.15407/pmach2018.02.060.

17. Бахвалов Н. С. Численные методы. М.: Наука, 1975. 632 с.

18. Рамм А. Г. О численном дифференцировании. Изв. вузов. Математика. 1968. № 11. С. 131-134.

19. Гилл Ф., Мюррей У., Райт М. Практическая оптимизация. М.: Мир, 1985. 509 с.

20. Тихомиров В. М. Рассказы о максимумах и минимумах. М.: Наука, 1986. 192 с.

21. Форсайт Дж., Малькольм М., Моулер К. Машинные методы математических вычислений. М.: Мир, 1980. $280 \mathrm{c}$.

22. Gander W., Gautschi W. Adaptive quadrature - revisited. BIT Numerical Mathematics. 2000. Vol. 40. Iss. 1. P. 84-101. https://doi.org/10.1023/A:1022318402393.

23. Mathews J., Fink K. Numerical methods using Matlab. 4nd ed. New Jersey: Prentice-Hall, 2004. 696 p.

24. Долгополова Т. Ф., Иванов В. К. О численном дифференцировании. Журн. вычисл. математики и мат. физики. 1966. Т. 6. № 3. С. 57-71. https://doi.org/10.1016/0041-5553(66)90145-5.

25. Островский А. М. Решение уравнений и систем уравнений. М.: Изд-во иностр. лит., 1963. 220 с. 